\title{
The Emerging Social Contract: State-Citizen Interaction after the Floods of 2010 and 2011 in Southern Sindh, Pakistan
}

\author{
Ayesha Siddiqi
}

\begin{abstract}
This article looks at the post-disaster context of Lower Sindh, a region devastated by super floods in 2010 and 2011, in an attempt to understand what government policies were implemented to assist people whose lives had been washed away. Based on fieldwork conducted in three districts of Lower Sindh this study emphasises that while a general narrative seems to suggest that the Pakistani state's post-disaster policies and interventions were insufficient, ineffective or both, there is significant evidence to demonstrate the relative success and universal outreach of government interventions. This also had a significant impact on food security in the aftermath of the disaster. The government response to the floods has in fact contributed towards a fundamental shift in state-citizen relations. This underdeveloped and still emerging 'disaster citizenship' in Pakistan is based on entitlements and rights rather than a citizenship more commonly understood to be based on identity, kinship or patronage.
\end{abstract}

\section{The absent state in disasters}

In examining citizen-state interaction during the 2010 and 2011 floods, this study focuses on climatic disasters in southern Sindh where they significantly disrupted the lives and livelihoods of people. Disasters are inherently political events. David Easton's classic characterisation of politics, describes it as 'the authoritative allocation of values' (Mitchell 1961). If politics is therefore an allocative framework, it is intuitive that disasters should be very political indeed, because values of crucial importance, including those of survival itself, are being allocated by the effective action or inaction of ruling regimes both before, but especially after, the disaster event (Drury and Ohlson 1998). Most scholars now agree that vulnerability to disasters 'is primarily a socio-political issue rather than a question of disaster-proof technology' (AlbalaBertrand 1993). While most political scientists and geographers accept that disasters 'occur in a political space' (Cohen and Werker 2008), drive politics in the disaster-affected region (Simpson and Corbridge 2006) and alter the political space available in the post-disaster era (Drury and
Ohlson 1998), it is the latter that this study is interested in examining, particularly the 'transformative' potential of the political space in the post-disaster context.

This article builds on the work of Pelling and Dill (2010) that discusses 'transformative political space' after a disaster. Examining the earthquake in Marmara, Turkey, they identify the disaster as a 'tipping point' or 'catalyst' that allowed civil society and affected communities to contest the very nature of the social contract between the state and its citizens. Their framework (elaborated by Pelling 2011) views disasters as representing a failure in the social contract and opening political/civil space for renegotiation, in structures and processes, between citizens and the state. Instability sets in when the dominant actor (duty-bearer) is unable to meet its responsibilities, leading to an opening in political space. Redistribution of power then depends on the manner and rate at which dominant actors respond to what Habermas refers to as a crisis of legitimacy and thus an exposed vulnerability in the social contract (Pelling and Dill 2010). If 
these changes in governable spaces and renegotiation of rights for human security have a long-term effect in revising or changing the very nature of the social contract, it is possible to conclude that a 'critical juncture' has been reached. This is the point that signifies an irreversible political change or composition in the structure of the incumbent regime (Pelling and Dill 2010). This study then specifically aims to discuss the nature of this political space in southern Sindh after the floods of 2010 and 2011 and the disasters as a 'tipping point' for change.

This 'transformative' change in the post-disaster context is to a large extent driven by challenges presented to the legitimacy and authority of the state and how the state responds to such a crisis. Needless to say, if the state disengages from the disaster altogether or closes this political space through repression or co-option, the opportunity presented by this 'catalyst' is either lost or only transitional and unable to sustain itself. The popular discourse on the Pakistani state after the floods in 2010 and 2011, however, was the former - that the state chose to remain 'absent' which is its default position. In previous research on rural Sindh, Kabeer et al. note that, 'the government is largely conspicuous by its absence in the study villages', which were located along the main road from Karachi in Sindh to the border with Balochistan (Kabeer et al. 2012). This idea that the state is 'absent' is hardly new, or unique to Sindh and is the dominant narrative for many parts of rural Pakistan.

The 'absent state' thesis of Kabeer and her colleagues was developed in a study that examined the comparative impacts of social transfers to poor households in Sindh, Pakistan and in West Bengal, India. Despite a number of similarities in the two regions, including income levels of the sample populations, the project had a significantly greater impact on poverty reduction in West Bengal than it did in Sindh. One of the primary reasons identified by the authors was that the project implementation agency in Sindh 'was attempting to address extreme poverty in a context where the state was largely absent. Many of the gains that its participants made were wiped out by forces that only a functioning state had the capacity to tackle - inflation in the price of food and raw materials, and deficits in social and physical infrastructure' (ibid.).
The study also illustrated that while in West Bengal the 'distance, accessibility and quality of service among government health facilities left much to be desired', it was still possible for most participants to seek out and use these government services. On the other hand, in Sindh, most interviewees did not have access to even poor-quality government facilities. Hence, when participants ${ }^{1}$ were questioned on what services they most needed in the village, the answers almost unanimously stated basic services such as health care, water or transport (ibid.).

This work on Sindh emphasised that, besides some water tanks installed by a government department ten years prior to the study, participants in the area studied by Kabeer had never had much interaction with the state. None of the villages had an electric power supply. Much like the water tanks, the state had also once built schools many years before the study but they were now 'ghost schools' either lying defunct or occasionally used by a local maulvi, holding unregistered classes on the premises (Kabeer et al. 2011). This study demonstrated that the majority of residents of rural Sindh seemed to have little interaction with the state.

The narrative that emerged after the worst floods in Pakistan's post- $1971^{3}$ history followed this idea of an 'absent' state. These floods had particularly affected a large proportion of the province of Sindh in 2010 and at the same time the following year the floods hit again, this time causing destruction in different parts of the province. The dominant discourse, during and post-disaster, remained that of a failing, if not altogether 'absent state'. After the floods that affected Sindh in 2011, international media reports said, 'Correspondents say the perception is that for a second year running, the government in particular has failed flood victims' (BBC 2011). Reporting from Sindh, after the 2010 floods, a journalist described public opinion in the following words: 'The tented refugees offered scathing criticism of their local parliamentarian, who they said did nothing to help, and the government in general' (Walsh 2010).

\section{Food security, disaster and citizens}

Climatic disasters, such as the floods of 2010 and 2011 in Sindh, also impact food security in the region; as demonstrated earlier this will affect political space and the social contract, which will 
be explored in some detail. In a paper examining the concept of food security in protracted humanitarian crises, Maxwell et al. describe a new era in disaster management, one where the annual number of humanitarian crises is increasing but fewer people are dying in these complex emergencies. Instead 'people are surviving to lead lives of increased chronic food insecurity and impaired development' and 'while not all of these crises would be described as "food emergencies", virtually all of them impact the food security of affected populations' (Maxwell et al. 2010).

Devereux discusses this negative effect on food security in the context of Sen's entitlement approach. In the context of famines and food security an 'entitlement set' is the full range of goods and services an individual can exchange for adequate food. 'Individuals face starvation if their full entitlement set does not provide them with adequate food for subsistence' (Devereux 2001). By implication then, they would face food insecurity and malnourishment if their full set of entitlements provides them with less than adequate food for healthy development. Devereux's work also presents a detailed analysis of the 'entitlement failures' that result as a consequence of climatic disasters, such as floods and drought, and emphasises the policy interventions that can prevent food insecurity or starvation. His policy solutions comprises a comprehensive social protection programme consisting of cash and asset transfers, employment safety nets and others (Devereux 2007a). While it cannot be argued that the state interventions after the floods in Sindh included the full range of measures recommended by Devereux, partial policy options in the form of cash transfers were instituted by the state and were visible in my field sites in the post-disaster context.

According to the theoretical framework utilised by this study, the flooding disaster of 2010 and 2011 was clearly a political event that fractured the social contract between the state and its citizens. If the state remained 'absent' and did not attempt to use the political space opened up by the disaster to reach out to its citizens, entitlement failures and mass starvation should result. In The New Famines, Devereux argued against the received wisdom that famines have 'receded into history', or that they only occur in countries that are either dictatorships or at war. His work presented case studies from countries in Africa, Asia and Europe, some of which were 'peaceful democracies' and where the contributory causes of the 'new famines' ranged from HIV/AIDS to international sanctions (Devereux 2007b). Hence it is worth investigating that, given what we know about 'new famines', why did a calamitous disaster such as the floods of 2010 and 2011, compounded by a state that was 'absent' and did not respond, not culminate in a climatic disaster-based famine?

A survey by the Economic Ministry (2011) after the 2011 floods illustrated that the damage to crops, livestock, poultry and fisheries was to the tune of US $\$ 1,840.3$ million. Sindh suffered the brunt of this loss with 94 per cent of the total damage. In the flood-affected villages where I did fieldwork, it was obvious that families and communities were still reeling from the loss of livelihoods and food consumption. In two or three villages, community members also showed me areas where even one year after the floods, fields were still flooded and planting a new crop was not possible. At the same time, however, all interviewees acknowledged that they were able to maintain a level of subsistence; during their time in the relief camps (whether government or NGO-run) they received regular supplies of food and rations. However, since coming back to their homes regular food supply seemed to be more of a concern.

I interviewed a middle-aged woman who I will call Amma. Amma is the resident of a small village in Badin district. She estimated that she was 45-50 years of age and that her husband was about 20 years her senior. Due to his age and failing health her husband was no longer able to work, so I asked her where her income came from. She replied gaily:

\section{For eight to nine months I have had no need for an income, daughter, I feed my family from the 'imdaad' [aid] I received after the floods [in 2011].}

When I asked Amma for details of what 'imdaad' she received, she mentioned money from the Watan Card ${ }^{4}$ in passing but especially emphasised large quantities (in kilograms) of food rations, such as wheat flour, rice and cooking oil she received from state and non-state actors. Amma also confirmed that she was not worried about 
food insecurity 'for a while' as she had enough 'imdaad' stored away (pers. comm. May 2012).

From the interviews and the fieldwork that I did, it was evident that during the disaster, while clean drinking water was an issue of concern for some of the flood-affected individuals, access to regular meals was not. In fact Interviewee 4 (a young mother in a village in Thatta) (pers. comm. June 2012) and Interviewee 5 (a middleaged man in a village in Badin) (pers. comm. May 2012) both said that if the state had not intervened in the manner that it did (Interviewee 5 specifically said with 'bank cards and rations'), they both independently of each other used the phrase 'hum bhookay, mar jatay [we would have starved to death]'. In other words, these individuals were crediting state interventions for preventing food insecurity during the disaster. The post-disaster situation however is more complex.

Food insecurity has been considered a crucial contributor to the political uprisings in the Arab world in 2011 (Zurayk 2011). A professor at SOAS (School of Oriental and African Studies, University of London) made the connection between the uprising and rising food prices in the following words: 'the food-price spike was the final nail in the coffin for regimes that were failing to deliver on their side of the social contract' (The Economist 2012). Despite two largescale disasters in the form of floods in 2010 and 2011, and a general dissatisfaction with the government and leaders in power, interviewees I spoke to in the villages in the districts of Thatta, Badin and Tharparkar did not make any reference to the state breaking its contract or abrogating its responsibility to its citizens.

Instead it often seemed that the state used the disaster to reach out to its citizens and forge a relationship that previously did not seem to exist.

\section{Disasters and the state}

I spent four months doing field research in three flood-affected districts of Lower Sindh in the summer of 2012. I interviewed 93 individuals and groups and did participant observations in three districts of southern Sindh: Thatta (affected by floods in 2010), Badin and Tharparkar (affected by floods in 2011). The interviewees' perceptions of state interventions post-floods supported this narrative of an 'absent' or incompetent state. I asked individuals and focus groups in approximately 50 villages what 'hakumat [government]' aid and assistance they received during and after the disaster. The most common answer was:

\section{Kuchbheenaheen [nothing at all].}

For instance, in a focus group discussion with men and women from a village in Badin district, a woman in her late twenties said:

They [the government] gave us nothing. Everyone has to help oneself. In such a super flood, no one provided us with a rescue vehicle or any other assistance. We went to Badin [city] on foot. We reached Badin on self-help basis. ${ }^{5}$ From here we travelled up to [the city of] Malkani, and then went to Badin. We took our small children and travelled $30-35 \mathrm{~km}$ in the rain.

This interviewee was explicit in stating that they received no support from the state during the disaster and detailed how difficult it was for them to reach safety and yet they managed only because they helped themselves. In this discussion, the interviewees used the words 'responsibility of' and 'failure of' most often, when talking about the 'government'. They expressed disappointment with a state that they expected would help but instead was 'absent' and unable to help during and post-disaster. A middle-aged man who was part of this focus group discussion clearly stated:
No one helped us. We were looking for help, the government had even declared it an 'emergency' [used the English word] but no one came to us to help. Nazims [local-level leaders] ${ }^{6}$ were inefficient, they are inefficient and will be inefficient in the future, inshallah ['God willing', added sarcastically].

These individuals categorically stated that the government had done 'nothing', and given them 'nothing' after the disaster. I then specifically asked this group of about 20 adults if they had received any money through the social protection programme that provided unconditional cash transfers to the head of every household who was resident in a flood-affected area. In response to that enquiry there was a resounding 'yes' all around. The money was provided to the flood affectees in 2011 through an ATM card called the Pakistan Card that was linked to Pakistan's digital database NADRA (National Database and Registration Authority) to ensure that all 
households in government notified flood-affected areas received the cash transfer. This programme was the successor of the Watan Card (UNHCR 2010) cash transfer scheme instituted after the 2010 floods. The interviewees went on to inform me that each household in this village had received a Pakistan Card and had withdrawn the full value of their cash transfer from the ATM machine.

Further conversations and questions also revealed that 12 households $^{7}$ out of a total of about 150 households in the village were regularly receiving money orders from the Benazir Income Support Programme (BISP), an unconditional cash transfer targeting the poorest households in the county (BISP 2011). These cash transfers had also reached the women during the floods, or were made in aggregate if a payment was missed due to logistical problems raised by the floods (pers. comm. June 2012).

Referring to the policy document, National Social Protection Strategy (NSPS) of 2007, published by the National Planning Commission of Pakistan, Gazdar points out that it 'represented a major advance in Pakistan in policy thinking about social protection'. The NSPS defined the role of social protection in more conventional terms as social insurance and risk mitigation as well as taking on the more challenging goal of 'social transformation'. BISP has an enviable record of being the first cash transfer programme to reach 7 per cent of all households in the country (Gazdar 2011), 40 per cent of the population living below the poverty line (BISP 2011) and is also 'by far the most gender-sensitive safety net intervention in Pakistan' (Khan and Qutub 2010). It is, however, the universal cash transfers in the form of the Watan Card and the Pakistan Card provided to all households in the government-declared flooded regions that were almost unprecedented in a post-disaster context in Pakistan. ${ }^{8}$

In my research site of about 50 villages in Thatta, Badin and Tharparkar, interviewees in only one village complained of not having received the Pakistan Card despite being in the flood-affected zone. All other interviewees, in each of the villages, in each of the three districts admitted to having received the first instalment of the Pakistan and Watan Cards, though almost all were frustrated that they were still owed either one (in the case of the Pakistan Card) or more (in the case of the Watan Card) instalments that they had not received. Given that approximately 1.6 million Watan Cards (UNHCR 2010) and about 1.25 million Pakistan Cards were issued (The Newes 2012), these were very large programmes with a record outreach.

The smart cards and ATM cards were a part of state interventions in the disaster-affected areas but it seemed harder for individuals to make the link back to the state. On the other hand, if a District Coordination Officer (DCO) or local politician had braved heavy rains to reach out to flood affectees with aid and relief, it was always mentioned in the context of a concerned, aiddelivering state. For many interviewees seeing an individual as a manifestation of the state was important. In a small town in Thatta district, when asked about state support after the floods, three different interviewees mentioned the name of a Deputy District Officer (DDO) who had worked diligently to provide relief goods to floodaffected populations. He represented the state reaching out to affected individuals and families. At the same time, however, almost none of the interviewees mentioned Watan or Pakistan Cards when questioned on state support postdisaster. Only when directly asked about these schemes or prompted to provide details about them did these cash transfers come up in interview conversations.

It is however important to mention that a few individuals were able to recognise the ways in which the state had reached out to affected individuals after the disaster. In one village in Thatta a middle-aged man, Interviewee 2, repeated the phrase 'Jo khaakayna many na Hindu naMusalmaan ${ }^{9}$ [implied meaning: one who accepts favours and then refuses to acknowledge them, is a hypocrite]' twice in the interview. He admitted to having voted for the incumbent Pakistan People's Party (PPP), and perhaps because of that political allegiance, detailed the way that the state provided him and most of his village support after the floods of 2010.

When we were in the 'sarkari' [state-run (relief)] camps the people of Karachi [where the camp was based] gave us a lot of respect, treated us well and looked after us, as did the government... They assisted us in a difficult time. In fact their assistance far exceeded our expectation... It was in the first 3-4 
years of Mr Bhutto's government ${ }^{10}$ that the poor people were able to breathe a sigh of relief, after that it is only now during Mr Zardari's tenure ${ }^{11}$ that the poor people have been provided assistance. Something or the other is being done to help the poor, whether it is in the form of Watan Card, Pakistan Card or the Benazir Income Support Programme. We were never aware of such programmes in the past, we had never even heard of them. The people in our village had never even seen an ATM. They did not know what an ATM card was (pers. comm. May 2012).

While they may sound like words of a party loyalist, the point Interviewee 2 made is still valid and very significant. This was the first time that the state in Pakistan reached out to affected individuals, suffering from the effects of a disaster, or poverty more generally, in a direct and responsive manner. Individuals received BISP money orders (now smart cards) or Watan or Pakistan ATM Cards, simply by virtue of the fact that they were affected 'citizens', signaling what Gazdar calls 'a paradigm shift' in state-citizen relations. The near universal targeting and link to the national database (NADRA) of these state interventions aims to establish a lasting interaction or contract between the state and its citizens. The emerging social contract accepts the people as the responsibility of the state.

This 'paradigm shift' however was not pulled out of a hat, neither did it occur in an unsystematic or entirely coincidental way. On the contrary, using 'social protection for nation building' was an explicit goal in the strategy paper, 'Final Report of the Panel of Economists' prepared by the Planning Commission, Government of Pakistan in April of 2010 just months before the first flooding disaster. In writing about the conflict-affected areas of the country, the document clearly stated, 'Social protection must be part of the strategy to reclaim the space and legitimacy for the state in Pakistan, through protection to the basic entitlements of people in the conflict-affected areas' (Pelling and Dill 2010). This policy statement is particularly significant when looking at the role such state interventions played after the flooding disaster in Sindh. Pelling and Dill's empirical work confirms that politically 'disaster outcomes are path dependent', an observation supported by one of the earliest works in disaster politics by Albala-Bertrand. She noted that 'responses to disasters vary according to the political visions of the major power-holders (endogenous and exogenous) and tend to reveal dominant political philosophies'. Hence it logically follows that because the state in Pakistan had already begun to conceptualise and implement (with geographical limitations) a policy of citizenship through social protection, the flooding disaster was able to push that objective along.

It is also noteworthy that in all areas of Thatta, Badin and Tharparkar where I did fieldwork, it was common for people to comment on a 'useless', 'incompetent' state that did nothing for them. In Tharparkar, however, the narrative of the region being an 'underdeveloped marginal area (pasmandaalaqa)' was repeated most frequently. Yet, even in what was considered the most peripheral area of Sindh, Interviewee 3, a small shop-owner in his late twenties from a town in Tharparkar, articulated what many interviewees had described as the main role of the state - to provide social services and policy interventions. When I directly asked him what he thought was the responsibility of the state towards its citizens, his reply was:

\section{It is like this, firstly we need 'light' [he used the English word 'light' commonly used in Pakistan to refer to electricity] in our village, we also need a water line and we need roads.}

In a different part of the conversation he had stated:
For our village roads have reached and electricity has reached as well. But till now a water line has not been provided to Nagarparkar. Work on the water line is under way but it is still about $25 \mathrm{~km}$ away from us (pers. comm. August 2012).

Interviewee 3 and some of his friends, who eventually contributed towards this discussion, were clear that the state left a lot to be desired. Yet without realising, through his own admission and the criteria of the citizens and the indicators with which they judged the state, it was particularly difficult to declare the state as 'absent' in this part of Sindh in Pakistan. The village in Nagarparkar had direct street access to a double-lane highway, it had an electricity connection and water was $25 \mathrm{~km}$ closer to being at its doorstep than ever before. Hence, the emerging social contract also seems to be 
constructed of a citizenry that demands more from the state and a state that in its capacity has to attempt to deliver.

\section{Disasters and the social contract in southern Sindh}

More than a decade after Alex de Waal's seminal work on famines and the social contract was published (De Waal 1997), there is renewed interest in understanding how disasters are affecting the interaction of the state and citizens in different parts of the world. O'Brien et al.'s recent work on changing social contracts in the face of climate-induced uncertainty examines case studies from industrialised societies and concludes that social contracts need to be 'continually' renegotiated so that they may be able to respond to and create change (O'Brien et al. 2009). Warner acknowledges that to rethink political structures and begin this process of renegotiation of the social contract 'it is therefore attractive for those seeking to break the status quo to push for the declaration of a disaster' (Warner, forthcoming) and use it as a platform for transformative change. This acceptance of a disaster makes it possible for political actors but also 'ordinary people' to challenge, question and criticise powerbrokers, something they may be unable to do otherwise. It may even be referred to as 'disaster citizenship' because 'it makes citizens out of victims, even if

\section{Notes}

1 Women in the lowest and middle-income brackets in three villages located between Karachi and Balochistan: Rais Mehmood Old (RMO), Rais Mehmood New (RMN), Noor Mohamed Goth (NMG) and Kundu.

2 Religious teacher.

3 December 1971 was when East Pakistan became the independent state of Bangladesh and Pakistan came into being in its contemporary form.

4 'Watan' means 'country' and the Watan Card refers to a cash transfer programme instituted by the state for flood victims.

5 They used the Urdu phrase 'apni madad aap', or the Sindhi phrase 'paanji madad' which translates as 'self-help'. This phrase was frequently used by flood-affected interviewees, to emphasise that they were left to fend for themselves, and the 'state' interventions and instruments were not available. such empowerment comes at a heavy price' (Pantti and Wahl-Jorgensen 2011).

De Waal presents a powerful argument in stating, 'freedom from famine (disaster) arises within a specific form of social contract, developed through political struggle' (De Waal 1996). In the post-disaster context of southern Sindh, sociopolitical struggles are taking place to challenge the nature of the interaction between the state and its citizens. Forces of change, including the flooding in southern Sindh are encouraging people to demand more of the state and its agents, who they helped put in office.

This article attempted to demonstrate the policy response of the state to the disaster, the extent to which it was successful in meeting people's expectations and how this impacts an emerging social contract in southern Sindh. While more research is needed, my research indicates that a devastating disaster, such as the floods in Sindh, resulted in people immediately demanding an interaction with a state that delivers aid and institutes policy solutions. Traditional views on a kinship- or patronage-based social contract were almost drowned out with the rising tide of the Indus River. The state for its part was neither as 'absent' nor as 'useless' as the dominant narrative seemed to suggest.

6 The Nazim was the chief elected official of a local government, at the level of the union, tehsil, or district under the Local Government Ordinance of 2001 that has now been replaced.

7 In this village, most of these were femaleheaded households. The women receiving the BISP cash transfers were widows and had limited income opportunities.

8 Cash transfers in the post-disaster context in Pakistan were first distributed after the Kashmir earthquake of 2005; however, they were implemented in a consolidated scheme such as the Watan or Pakistan Cards.

9 Literal translation: One, who eats and doesn't acknowledge it, is neither Hindu nor Muslim.

10 Zulfiqar Ali Bhutto was founder of the Pakistan People's Party (PPP) and Prime Minister of Pakistan 1973-7.

11 Asif Ali Zardari is the incumbent President of Pakistan since 2008 and co-chairman of the PPP. 


\section{References}

All websites accessed February 2013.

Albala-Bertrand, J.M. (1993) The Political Economy of Natural Disasters: With Special Reference to Developing Countries, Oxford: Oxford University Press

BBC (2011) Agencies Warn of Acute Pakistan Flood Relief Shortfall, BBC News online, 9 November, www.bbc.co.uk/news/world-asia-15643468

BISP (2011) Benazir Income Support Programme website, www.bisp.gov.pk/ Cohen, C. and Werker, E. (2008) The Political Economy of 'Natural' Disasters, Working Paper 08-040, Boston MA: Harvard Business School

De Waal, A. (1997) Famine Crimes: Politics and the Disaster Relief Industry in Africa, London: African Rights, International African Institute

De Waal, A. (1996) 'Social Contract and Deterring Famines: First Thoughts', Disasters 20.3: 194-205

Devereux, S. (2007a) 'The Impact of Droughts and Floods on Food Security and Policy Options to Alleviate Negative Effects', Agricultural Economics 37.S1: 47-58

Devereux, S. (2007b) 'Introduction: From "Old Famines" to "New Famines", in Stephen Devereux (ed.), The New Famines: Why Famines Persist in an Era of Globalisation?, Abingdon: Routledge Studies in Development Economics Devereux, S. (2001) 'Sen's Entitlement Approach: Critiques and Counter-critiques', Oxford Development Studies 29.3: 245-63

Drury, A.C. and Ohlson, R.C. (1998) 'Disasters and Political Unrest: An Empirical Investigation', Journal of Contingencies and Crisis Management 6.3: 153-61

Economic Ministry (2011) 'Flood Impact Assessment, Special Section', Pakistan Economic Survey 2011-2012

The Economist (2012) 'Food and the Arab Spring: Let them Eat Baklava', 17 May, www.economist.com/node/21550328

Gazdar, H. (2011) 'Social Protection in Pakistan: In the Midst of a Paradigm Shift?', Economic and Political Weekly XLVI.28

Kabeer, Naila; Huda, Karishma; Kaur, Sandeep and Lamhauge, Nicolina (2012) 'Breaking Multiple Constraints on Poor Women's Livelihoods', CDPR Development Viewpoint 73, www.soas.ac.uk/cdpr/publications/dv/breakingthe-multiple-constraints-on-poor-womenslivelihoods.html

Kabeer, Naila; Kaur, Sandeep and Lamhauge, Nicolina (2011) 'And Who Listens to the Poor?'
Shocks, Stresses and Safety Nets in India and Pakistan, Dhaka: BRAC Development

Institute, www.graduation.cgap.org/wp.../AndWho-Listens-to-the-Poor-FINAL.pdf

Khan, S.N. and Qutub, S. (2010) The Benazir Income Support Programme and the Zakat Programme: A Political Economy Analysis of Gender, ODI Working Paper, London: Overseas

Development Institute

Maxwell, Daniel; Webb, Patrick; Coates, Jennifer and Wirth, James (2010) 'Fit for Purpose? Rethinking Food Security Responses in Protracted Humanitarian Crises', Food Policy 35.2: 91-7

Mitchell, W.C. (1961) 'Politics as the Allocation of Values: A Critique', Ethics: An International Journal of Social, Political and Legal Philosophy 71.2: 79-89

The News (2012) '1.248 Million Cards Issued in Sindh says Nadra', The News Online, 27 July, www.thenews.com.pk/Todays-News-2-1230191248-million-Pakistan-Cards-issued-in-Sindhsays-Nadra

O'Brien, K.; Hayward, B. and Berkes, F. (2009) 'Rethinking the Social Contract: Building Resilience in a Changing Climate', Ecology and Society 14.2: 12

Pantti, M.K. and Wahl-Jorgensen, K. (2011)

"Not an Act of God": Anger and Citizenship in Press Coverage of British Man-made Disasters', Media, Culture and Society 33.1: 105-22

Pelling, M. (2011) Adaptation to Climate Change: From Resilience to Transformation, Abingdon: Routledge

Pelling, M. and Dill, K. (2010) 'Disaster Politics: Tipping Points for Change in the Adaptation of Socio-political Regimes', Progress in Human Geography 34.1: 21-37

Simpson, E. and Corbridge, S. (2006) 'The Geography of Things that may Become Memories: The 2001 Earthquake in KachchhGujarat and the Politics of Rehabilitation in the Prememorial Era', Annals of the Association of American Geographers 96.3: 566-85

UNHCR (2010) The WATAN Scheme for Flood Relief: Protection Highlights 2010-2011, Pakresponse.info online. http://floods2010.pakresponse.info/ Walsh, D. (2010) 'Still Marooned: Plight of Flood-stricken Villagers in Pakistan's Sindh Province', The Guardian Online, 4 October, www.guardian.co.uk/world/2010/oct/04/pakista n-floods-plight-sindh-province 
Warner, J. (forthcoming) 'The Politics of Catastrophisation', Disaster Studies, Routledge Zurayk, R. (2011) 'Use your Loaf: Why Food Prices were Crucial in the Arab Spring', The Observer Online, 17 July, www.guardian.co.uk/lifeandstyle/2011/jul/17/b read-food-arab-spring 